\title{
Transplantasi Organ Tubuh sebagai Pengganti Hukuman Qhisas dalam Hukum Islam (Studi Terhadap Delik Pelukaan Mata)
}

\author{
Amin Ramly \\ Fakultas Ekonomi dan Bisnis Universitas Pattimura, Ambon, Indonesia \\ E-mail: aminramly70@yahoo.co.id
}

\begin{abstract}
This paper deals with the study of Islamic criminal law, which regulates the study of transplants as a substitute for Qhishas punishment, the main issue is to see how the qhisas process of ophthalmic offenses, eye transplantation techniques, and fiqh analysis of eye transplants as a substitute for qhisas punishment. To be able to analyze the problems above, this study uses a type of qualitative research with a normative approach based on the rules of Islamic law (Al-Quran, hadith, and ijtihad), and analyzed by the inductive method according to the Shari'a perspective on the concept of transplantation as qhisas punishment. The results showed that the qhisas for the eye opening offense based on the argument of Al-Maidah verse 45, where the eye must be punished with the eyes, both in terms of the method of wounding practiced must be balanced between the victim and the offender, while the diyat above the eye opening offense is 100 dinars. The eye organ transplant can be done medically by removing the cornea of the eye rather than the eyeball, because the eyeball cannot be transplanted, and the transplant is carried out from the donor to the recipient on all medical requirements by medical means. The analysis of jurisprudence to the concept of eye transplantation as a substitute for the qhishas penalty in sharia is not allowed, because it does not meet the principle of qhishas justice, namely the balance between uqubah with deeds, where the offender is charged with qhishas punishment (medical eye opening) and also charged with diyat punishment (ie costs transplant operations that will be borne by the perpetrator) whose amount can be more than diyat value.
\end{abstract}

Keywords: Organ transplants; Punishment Qhishas.

\section{A. PENDAHULUAN}

Hukum islam merupakan sesuatu yang tidak mungkin mengalami perubahan, karena berdasarkan wahyu Allah yang bersifat qadim. Setiap qadim bersifat statis tidak berubah, hal ini kemudian ditafsirkan sebagai sumber yang bersifat illahiyah, namun dari sudut pandang lain, hukum islam tidak bersifat statis tetapi mempunyai daya lentur yang dapat sejalan dengan sesuatu yang bergerak, dalam konteks ini hukum islam dapat mengalami perubahan berdasarkan kondisi dan perkembangan masyarakat, hal ini kemudian ditafsir sebagai bentuk rekonstruksi piker dalam pikiran hukum yang dalam 
konteks hukum islam atau syariah disebut dengan ijtihad atau hasil kreasi manusia terhadap hukum ${ }^{1}$.

Sacipto Rahardjo mengemukakan bahwasannya susbtansi hukum adalah untuk manusia dan dipandang sebagai sarana untuk merekayasa sosial (Law as a Tool of Social Engineering), sehingga hukum harus berorientasi ke masa depan bukan ke masa lampau hingga pada akhirnya harus berperan aktif guna menimbulkan pembaharuan dalam masyarakat, dan fungsi hukum tidak hanya untuk menciptakan ketertiban, namun mendorong perubahan yang signifikan dalam masyrakat ${ }^{2}$.

Korelasi perubahan sosial masyarakat sebagai refleksi perkembangan zaman terhadap perubahan hukum dalam kontekstual syariah, dapat ditelusuri pada berbagai macam permasalahan sosial dan perkembangan, dengan berdasarkan pada asumsi konsep ijtihad sebagai bentuk penemuan hukum ${ }^{3}$.

Dalam terminologi jinayah, hukuman qhishas atau jarimah qhishas adalah hukuman yang ditetapkan menurut syara' sebagai hak korban sehingga terhadap pelaku dapat dimaafkan oleh korban dan digantikan dengan hukuman diyat yakni denda yang ketentuannya diatur oleh hakim secara adil, namun jika tidak dimaafkan oleh korban, maka sanksinya akan dibebankan setara dengan perbuatan pelaku terhadap korban ${ }^{4}$.

Berdasarkan kontekstual qhishas, dapat dipahami bahwa suatu delik yang mengakibatkan hilangnya salah satu anggota tubuh atau rusaknya salah satu bagian tubuh akibat perbuatan pidana. Dalam kaitannya dengan transplantasi sebagaimana yang ditafsirkan sebagai bentuk pemidanaan organ tubuh yang mempunyai daya hidup yang sehat untuk menggantikan organ tubuh yang tidak sehat ${ }^{5}$.

Muhammad Sa'adih mengatakan dalam tulisannya tentang transplantasi dan hukuman Qhishas delik pelukaan, hal ini menunjukan bahwa kedudukan transplantasi sebagai model kebaharuan hukum Qhishas mendapatkan posisi penting untuk dilakukan pengkajian ulang, berkenan dengan ikhtilaf yang muncul mengenai problematika transplantasi sebagai pengganti hukuman Qhishas.

Dari uraian Pada latar belakang tersebut, maka yang menjadi permasalahan dalam tulisan ini adalah: "bagaimana pelaksanaan Qhisas pada delik pelukaan mata dan mekanisme transplantasi mata sebagai pengganti hukuman Qhishas, selain itu juga untuk mengetahui tentang kajian Fiqih terhadap konsep transplantasi sebagai pengganti hukuman Qhishas."

\section{B. METODE PENELITIAN}

Penelitian hukum ini akan menjawab isu permasalahan hukum sebagaimana di atas. Penelitian ini menggunakan penelitian yuridis normatif, yakni studi kepustakaan dimana referensi-referensi yang diperoleh merujuk ketentuan Fiqh Jinayah, menurut sumber hukum Al-Quran, Hadits, ijtihad, serta teori-teori hukum islam yang berlaku, referensireferensi penelitian yang terkait dalam hukum pidana islam. Proses pengumpulan data

1 Scacht, Yoseph. (1964). An Introduction to Islamic Law, Oxford, Oxford: Universty Press, p. 1.

2 Kusuma, Mahmud. (2009). Menyelami Semangat Hukum Progresif, Terapi Paradigmatic Bagi Lemahnya Penegakan Hukum Indonesia, Jogjakarta: Antony Lib-Indonesia, h. 103.

3 Soekanto. (1982). Sosiologi Suatu Pengantar, Jakarta, Grafindo, h. 24.

4 Muchlis, Ahmad Wardi. (2004). Hukum Pidana Islam, Jakarta: Sinar Grafika, h. 9.

5 Jamaa, La. (2013). Transplantasi Organ Tubuh, dalam Fiqh Kontemporer, Ambon: FSEI Press, h. 47 . 
menggunakan literasi, interview. Dan metode analisa data dalam penelitian ini dianalisa secara Deskriptif Analitis.

\section{PEMBAHASAN}

\section{Transplantasi Organ Tubuh Manusia dan Ketentuan Pidana dalam Hukum Islam}

Transplantasi merupakan salah satu temuan teknologi kedokteran modern dengan menggunakan metode kerja berupa pemindahan jaringan atau organ tubuh dari satu tempat ke tempat yang lainnya, hal ini dapat dilakukan pada satu individu atau dua individu. Transplantasi dilakukan dnegan tujuan pengobatan penyakit sebagai berikut:

1) Pengobatan serius, jika tidak dilakukan transplantasi maka akan berakibat pada kematian. seperti transplantasi jantung, ginjal, dan hati.

2) Pengobatan yang dilakukan untuk menghindari cacat fisik yang akan menimbulkan gangguan psikologi pada penderita, seperti transplantasi kornea mata, dan menambal bibir sumbing, transplantasi jenis ini dilakukan bukan untuk menghindari kematian, tetapi sekedar pengobatan untuk menghindari cacat seumur hidup ${ }^{6}$

Djamauddin Miri membagi transplantasi menjadi dua bagian:

1) Transplantasi jaringan seperti pencangkokan kornea mata

2) Transplantasi organg seperti pencangkokan organ ginjal, jantung, dan sebagainya ${ }^{7}$.

Melihat hubungan genetik antara donor (pemberi jaringan atau organ yang akan ditransplantasi) dan resipien ( orang yang akan menerima jaringan atau organ yang akan ditransplantasikan) ada tiga macam pencangkokan:

1) Auto transplantasi, yaitu transplantasi dimana donor resipiennya satu individu, seperti orang yang pipinya dioperasi, untuk memulihkan bentuk, diambilkan daging dari bagian badannya yang lain dalam badannya sendiri. Pada auto transplantasi hampir selalu tidak pernah mendatangkan reaksi penolakan, sehingga jaringan atau organ yang ditransplantasikan hampir selalu dapat dipertahankan oleh resipiennya dalam jangka waktu yang cukup lama.

2) Homo transplantasi, yakni dimana transplantasi itu donor dan resipiennya individu yang sama jenisnya, (jenis disini bukan jenis kelamin, tetapi jenis manusia dengan manusia). Pada homo transplantasi ini terjadi donor dan resipiennya dua individu yang masih hidup, bisa juga terjadi antara donor yang telah meninggal dunia yang disebut cadaver donor, sedang resipien masih hidup.

3) Hetero transplantasi, ialah yang donor dan resipiennya dua individu yang belainan jenis, seperti transplantasi yang donornya adalah hewan sedangkan resipiennya manusia. Pada homo transplantasi dikenal tiga kemungkina yaitu:

a) Apabila resipiennya dan donor adalah saudara kembar yang berasal dari satu telur, maka transplantasinya hampir selalu tidak menyebabkan reaksi penolakan. Pada golongan ini hasil transplantasinya serupa dengan hasil transplantasi pada auto transplantasi.

6 Umar, Hasbi. (2007), Nalar Fiqih Kontemporer, Jakarta: Gaung Persada Press, h.180.

7 Faquha, Ahkamul, Solusi Problematika Aktual Hukum Islam, Keputusan Muktamar, Munas, Dan Konbes Nahdlatul Ulama, (1926-2004 SM). Pen, Djamaluddin Miri. (2007), Surabaya: Khalista, h. 460. 
b) Apabila resipiennya dan donor adalah saudara kandung atau salah satubya adalah orang tuanya, maka reaksi penolakan pada golongan ini lebih besar daripada golongan pertama, tetapi masih lebih kecil daripada golongan ketiga.

c) Apabila resipiennya dan donor adalah dua orang yang tidak ada hubungan saudara, maka kemungkinan besar transplantasi selalu menyebabkan reaksi penolakan.

Dalam Islam, prinsip dasar tentang pengaturan kehidupan bermasyarakat adalah untuk mewujudkan kemaslahatan atau kesejahteraan manusia secara umum, yang mana tujuan substantive universal yang disyariatkan hukum islam adalah untuk menciptakan kemaslahatan manusia didunia dan akhirat dengan menjamin kebutuhan primer dan memenuhi kebutuhan sekunder serta tersier bagi mereka ${ }^{8}$.

Maksud pokok hukuman dalam islam adalah memelihara dan menciptakan kemaslahatan manusia dan menjaga mereka dari hal-hal yang mafsadah. Dengan demikian hukuman yang baik adalah hukuman yang mampu memenuhi kebutuhan sebagai berikut:

1) mampu mencegah seseorang dari perbuatan maksiat (preventif) dan mampu menjerakannya setelah terjadinya perbuatan (preventif).

2) batas tertinggi dan terendah suatu hukuman disesuaikan dengan kebutuhan kemaslahatan masyarakat.

3) memberikan hukuman bukanlah untuk membalas dendam namun untuk kemaslahatan masyarakat.

4) hukuman adalah upaya terakhir dalam menjaga seseorang agar tidak jatuh dalam suatu maksiat. Karena seseorang akan terjaga dari perbuatan maksiat apabila memiliki iman yang kokoh, berahlak mulia dan adanya sanksi duniawi yang diharapkan mencegah seseorang kedalam tindak pidana ${ }^{9}$.

Dalam hukum islam atau ketentuan fiqih jinayah atau pengaturan perkara pidana yang diatur berdasarkan putusan hukuman (uqubah), dimana ketentuan hukumnya terbagi atas 3 bagian yaitu, Jamriah Hudud, Jamriah Qishas, Dan Jamriah Ta 'zir.

1) Jamriah Hudud, adalah jamriah yang diancam dengan hukuman had.Abdul Qadir Audah menjelaskan bhawa hukum had adalah hukuman yang tekah dtentukan oleh syara' dan hak Allah ${ }^{10}$.

Ciri-ciri khas jamriah hudud adalah:

a) hukumnya ditentukan oleh syara' dan tidak ada batas minimal dan maksimal.

b) hukuman tersebut merupakan hukuman allah semata-mata, atau kalau ada hak manusia di samping Allah, maka hak Allah yang lebih dominan.

2) Jamriah Qhisas dan Diat, merupakan hukuman qhisas atau diat, baik qhisas maupun adat, keduanya adalah hukuman yang ditentukan oleh syara', perbedaan antara hukum had dengan hukum qhisas adalah bahwa hukum had merupakan hukum Allah (hak masyarakat), sedangkan qhisas dan diat merupakan hak manusia (hak individu).

8 Madjid, Syachril Abdul, (2010). Implementasi Undang-Undang Pelayaran Nomor 17 Tahun 2008, Tentang Kelautan Kapal, Dalam Skripsi Fakultas Syariah IAIN Ambon, h. 46.

9 Hanafi, Ahmad. (1993), Asas-Asas Hukum Pidana Islam, Jakarta: Bulan Bintang, h. 14.

10 Abd. Al. Qadir Al Audah, At Tasyari Al Jinayah Al Islamiy, Jus 1, Beirut: Dar Al Kitab Al Arabim Beirut, h. 609. 
3) Jamriah Ta'zir, adalah hukuman berupa pendidikan atas dosa (tindak pidana) yang belum ditentukan hukumnya oleh syara', penentuan hukuman ini diserahkan kepada ulil amri. Dalam konsep fikih jinayah suatu perbuatan dapat dianggap sebagai perbuatan jamriah jika memenuhi unsure-unsur:

a) Unsur materil (ar-rukn al-Maddiy), yakni adanya tingkah laku yang membentuk jamriah baik berupa perbuatan-perbuatan nyata atau perbuatan tidak nyata.

b) Unsur formil (ar-rukn asy-syar'i) adanya nash yang melarang perbuatan dan mencantumkan hukuman terhadapnya.

c) Unsur moril (ar-rukn al-Adabby) adanya pelaku adalah orang mukallaf, yang dapat dimintai pertanggung jawaban terhadap jamriah yang diperbuatnya ${ }^{11}$

\section{Mekanisme Pelaksanaan Hukuman Qhisas Pada Delik Pelukaan Mata}

Sanksi pidana dalam hukum islam disebut dengan al-Uqubah, maksudnya adalah bahwa hukuman dapat dikenakan setelah adanya pelanggaran atas ketentuan hukum, uqubah dapat dikenakan pada setiap orang yang melakukan kejahatan yang dapat merugikan orang lain baik dilakukan oleh orang muslim atau yang lainnya ${ }^{12}$.

Secara terklasifikasi, para ulama membagi jinayah terhadap tubuh (pelukaan) menjadi lima macam, Yaitu,

1) Ibanat Al-Atraf, memotong anggota badan, termasuk didalamnya pemotongan tangan, kaki, jari, hidung, gigi, dan sebagainya.

2) izhab ma'a al-Atraf, menghilangkan fungsi anggota badan (anggota badan itu tetap ada tetapi tidak berfungsi), contohnya korban buta, tuli, bisu, dan sebagainya.

3) Asy-Syaj, pelukaan terhadap kepala dan muka (secara khusus)

4) Al-Jarh, pelukaan terhadap selain wajah dan kepala termasuk didalamnya pelukaan yang sampai ke dalam perut rongga dada.

5) pelukaan yang tidak termasuk kedalam salah satu dari keempat jenis pelukaan diatas $^{13}$.

Hukum pidana islam penganiayaan tidak dipakai, yang ada dalam hukum pidana islam adalah jamriah/jinayah terhadap selain jiwa. Abu Bakar Jabir al-jazairi menyebutkan bahwa jinayah terhadap tubuh bisa berupa jinayahtul atraf, asy-syijjaj, dan al-jirah, jinayahtul atraf dalah perbuatan seseorang terhadap orang lain yang menyebabkan sakit atau cacat tubuh, seperti, mencungkil mata, dan mematahkan kaki, atau memotong tangan orang lain ${ }^{14}$, Asy-syijjaj adalah pelukaan terhadap orang lain padabagian kepala dan wajah, sedangkan al-jirah adalah pelukaan terhadap tubuh orang lain pada selain kepala dan wajah.

Demikian untuk mengetahui suatu perbuatan itu dipandang debagai jarimah dan pelakunya dapat dikenai pertanggungjawaban pidana apabila telah terpenuhi beberapa unsur yaitu: a. unsur formil, adanya ketentuan yang melarang teradapa suatu perbuatan yang diancam dengan hukuman, b. unsur materil, yakni perbuatan yang melwan hukum

11 Djazuli, A. (1996). Fiqh Jinayah. Bandung: Raja Grafindo Persada, h. 46.

12 Abdurrahman, (1992). Hukum Pidana Menurut Syari'at Islam. Jakarta: Rineka Cipta, h. 6.

13 Santoso. Topo Membumikan Al-Quran, tp, tt, h. 38 430.

14 Al-Jazairi, Abu Bakar Jabir. (1995). Minhaj Al-Muslim (cet. Ke-1), Beirut: Dar al Fikr, h. 429- 
baik itu perbuatan nyata-nyata berbuat atau sikap tidak berbuat, c. unsur moril, yaitu unsur yang terdapat pada pelaku, pelaku jarimah haruslah mukallaf, yaitu orang yang dapat dimintai pertanggungjawaban terhadap jarimah yang dilakukannya. ${ }^{15}$

Sanksi-sanksi yang hendak diterapkan terhadap orang yang melakukan tindak pidana terhadao tubuh menurut hukum pidana harus memenuhi syarat-syarat: a. pelaku berakal, b. sudah mencapai umur baliq, c. motivasi kejahatan disengaja, d. hendajnya darah orang yang dilukai sederajat dengan darah orang yang melukai, yang dimaksudkan dengan sederjat adalah hanya dalam hal kehambaan dan kekafiran. ${ }^{16}$

Syarat-syarat dilakukannya qhisas dalam delik pelukaan yaitu:

1) tidak adanya kebohongan didalam pelaksanaan, maka apabila ada kebohongan maka tidak boleh diqisas.

2) memungkinkan untuk dilakukan qisas, apabila qisas tidak dimungkinkan untuk dilakukan maka diganti dengan diyat.

3) anggota yang hendak dipotong serupa dengan yang terpotong, baik dalam nama atau bagian yang telah dilukai, maka tidak dipotong anggota kanan karena anggota kiri, tidak dipotong tangan karena memotong kaki, tidak dipotong jarijari yang asli (sehat) karena memotong jari-jari tambahan.

4) adanya kesamaan 2 (dua) anggota, maksudnya adalah dalam hal kesehatan dan kesempurnaan, maka tidak dipotong tangan yang sehat karena memotong tangan yang cacat dan tidak diqisas mata yang sehat karena melukai mata yang sudah buta.

Apabila pelukaan itu pada kepala atau wajah (asy-syikkak), maka tidak dilaksanakan qisas, kecuali anggota itu tidak berakhir pada tulang, dan setiap pelukaan yang tidak dimungkinkan untuk dilaksanakan qisas dalam pelukaan yang mengakibatkan patahnya tulang juga dalam jaifah, tetapi diwajibkan diyat dalam hal tersebut.

\section{Analisis Hukum Islam Terhadap Konsep Transplantasi Sebagai Pengganti Hukuman Qhishas}

Seacara konseptual, maqashid al-syariah berarti maksud atau tujuan disyariatkannya hukum islam, karena itu yang menjadi bahasa utama didalamnya adalah mengenai hikmah dan ilat ditetapkan suatu hukum, dimana norma, perilaku dan jalan hidup yang lurus harus sesuai dengan syariah. ${ }^{17}$

Tujuan hukum harus diketahui dalam rangka mengetahui apakah suatu kasus masih dapat diterapkan berdasarkan satu ketentuan hukum, karena adanya perubahan struktur sosial, hukum tersebut tidak dapat diterapkan, dengan demikian pengetahuan maqashd alsyariah menjadi syarat bagi keberhasilan mujtahid dalam ijtihadnya, hal ini dikarenakan bahwa inti dari maqashid al syariah adalah untuk mencapai kemaslahatan, karena tujuan penetapan hukum dalam islam adalah untuk menciptakan kemaslahatan dalam memelihara tujuan-tujuan syara. ${ }^{18}$

Pengaturan hukuman qhisas yang merupakan cabang dari pidana islam, merupakan substansi hukum islam yang bertujuan memberikan perlindungan hukum terhadap jiwa manusia, yakni terpeliharanya ancaman pembunuhan dan penganiayaan, dalam konteks

\footnotetext{
15 Hanafi, A. (1976). Asas-Asas Hukum Pidana Islam (cet. Ke-2). Jakarta: Bulan Bintang, h. 9.

16 As-Sayyid Sabiq, Fiqh Jilid III, tp, tt, h. 38

17 As-Syatibi, Abu Ishaq. Al-Muqafaqat Fi Ushul A;-Syariah, Juz II, Kairo: Mustafa Muhammad, tp, tt, h. 10

18 Ahmad Al-Mursi Husain Jauhar, Maqashid
} 
perlindungan hukum syariah memberikan pengaturan bersifat ancaman sanksi yang akan dibalas serupa apabila seseorang akan melakukan tindakan yang dilarang Allah dalam konteks jarimah (pembunuhan dan penganiayaan). Hal ini sebagaimana disebutkan dalam surat al-baqarah ayat 178 dan surat al-maidah ayat 45 .

Lebih lanjut dalam tasiran ibnu katsir, dijelaskan secara substansial berkenan dengan kedudukan surat Al-Baqarah ayat 178 bahwa asbab nuzul ayat ini berkenaan dengan budaya orang jahiliyah yang mengatur perkara pembunuhan, apabila bani nadir membunuh bani quraiz, maka pembunuh dari bani nadir tidak dikenakan hukuman balasan melainkan hanya membayar tebusan berupa 100 (seratus) wasaq kurma. ${ }^{19}$ Demikian pula dengan surat al-maidah berdasarkan asbab nuzulnya dengan peristiwa yang sama dengan surat Al-Baqarah ayat 178 .

Demikian Jika didasarkan kepada kedua surat tersebut kedudukan hukum qhisas secara umum memiliki fungsi yang tidak dapat digantikan dengan hukuman lain, karena substansi dalam konteks qhisas adalah ditegakanya keadilan hukum berdasarkan syaria Allah , karena dalam ketetapan qhisas terdapat kelangsungan hidup bagi orang-orang yang berakal, hal ini diinterpretasikan berdasarkan ancaman bagi pelakunya yang dibalas dengan perbuatan yang setimpal, dan dalam urgensi qhisas tidak dapat digantikan dengan hukuman lain, selain dari adanya pemaafan dari korban/wali korban, dan pengambilan diyat atas perbuatan jinayahnya, maka dengan demikian perbuatan itu dilakukan dengan sengaja, pelakunya juga akan mendapatkan balasan dengan hasil yang serupa. ${ }^{20}$

Hukum transplantasi sebagai pengganti qhisas memiliki dua pertimbangan yuridis yang dijadikan sebagai dasar pertimbangan istinbath terhadap kedudukan hukum transplantasi mata sebagai pengganti qhisas, yakni kedudukan transplantasi itu sendiri sebagai tujuan medis (kemaslahatan) dan kedudukan transplantasi sebagai tujuan hudu, transplantasi mata dalam tujuan kemaslahatan dianalisis secara syar'I maka dapat digambarkan bahwa terjadinya ikhtilaf dikalangan para ulama, dimana beberapa ulama fiqih klasik sepakat dengan menyambung organ tubuh manusia dengan organ tubuh manusia boleh selama organ lainnya tidak didapatkan. ${ }^{21}$

Sedangkan al-Bujayrami, dalam fathu al-wahhab mengatakan, bahwa tidak diperbolehkannya menyumbang tulang hewan dengan tulang manusia, jika yang lainnya masih ada dan walaupun tulang hewan yang najis seperti anjing dan celeng, ${ }^{22}$ dalam konteks yang lain, pakar hukum islam kontemporer berbeda pendapat akan boleh tidaknya transplantasi organ tubuh manusia, seperti disebutkan oleh ulama Saudi, Ibn bin Baz yang mengatakan bahwa praktek transplantasi organ tubuh manusia kepada manusia yang lainnya tidak boleh berdasarkan Haditz Nabi SAW yang mengatakan bahwa "merusak tulang orang mati hukumnya sama dengan merusak tulang orang hidup". ${ }^{23}$

Berdasarkan penjelasan diatas dapat dipahami bahwa transplantasi dalam hukum islam terdapat perselisihan pendapat dalam hal ini ada yang melarang praktek tersebut secara mutlak berdasarkan Haditz nabi SAW. Selanjutnya tujuan transplantasi sebagai tujuan Hudud dianalisis bahwa jika hukum didasarkan pada pendapat ulama yang tidak membolehkan, maka secara yuridis pula hukum transplantasi untuk tujun Hudud, juga

19 Wasaq adalah satuan ukuran berat dalam pengukuran orang-orang arab, dimana 1 wasaq sama dengan 60 gantang sha, sedangkan 1 sha sama dengan $2.176 \mathrm{Kg}$.

20 Al-Jazairi, Abu Bakar Jabir. (1995). Minhaj al-Muslim (cet. Ke-1). Beirut: Dar al-Fikr, h. 425.

21 Al-Nawawi, Yahya. (1992). Minhaj al-Talibin, Lebanon, dar al-Fikr, , h. 31.

22 Al-Bujayrami, Sulayman. (1998). Hashiyah Sharsh Manjhaj al Tjullab, vol 1, Lebanon: Dar, AlFikr, , h. 345-346.

23 Sulaiman bin Abu Daud, Sunan Abu Daud, vol 2 (tt: Dar al-Fikr, tt), h. 231. 
tidak dapat diperbolehkan, namun jika berpendapat sebaliknya, maka terhadap kedudukan transplantasi untuk tujuan Hudud tidak serta merta diperbolehkan, hal ini harus diinterpretasi juga dari tujuan ditegakannya hukum islam itu sendiri. ${ }^{24}$

Secara analitis, interpretasi terhadap kedudukan transplantasi mata terhadap tujuan Huhud, adalah berbeda dengan tujuan medis, dimana tujuan medis lebih mengutamakan kemaslahatan kondisi jiwa seseorang pada awalnya berada pada kondisi normal, kemudian mengalami suatu musibah dan dilakukan tindakan medis ketika hasil dari diagnosanya mengalami kebutaan dan menimbulan rasa aman bagi subjek, sedangkan transplantasi mata untuk tujuan Hudud, bisa ditafsirkan sebagai sebuah proses penggantian mata pelaku pidana kepada korban akibat dari perbuatan pidana yang dilakukan oleh si pelaku. ${ }^{25}$

Sebagaimana disebutkan oleh Al-Imam Nawawi dalam syarah arbain an-nawai, haditz nomor 6. Dapat ditarik kesimpulan bahwa:

1) transplantasi sebagai pengganti hukuman qhisas tidak diperbolehkan,

2) bahwa kedudukan transplantasi sebagai pengganti hukuman qhisas adalah suatu hal yang baru dan masih menjadi perdebatan dikalangan para ulama.

3) hukuman qhisas merupakan hukuman pidana (jarimah) sehingga penggantian Qhisas dengan metode transplantasi hanya paradigma kemaslahatan berdasarkan acuan analogi atau qiyas sebagai bentuk penemuan hukum.

Lebih lanjut jika analogi ini menjadi dasar pertimbangan hukum qhisas dengan adanya penggantian organ tubuh pelaku terhadap korban, maka secara logis pula aspek hukuman Jarimah qhisas harus dapat diberlakukan keseluruhan baik terhadap perkara penganiayaan ringan, sedang, berat, dan bahkan termasuk pada jiwa.

\section{PE N T U P}

Berdasarkan hasil penelitian ini maka dapat disimpulkan bahwa: pelaksanaan transplantasi organ tubuh sebagai pengganti qhisas dalam delik pelukaan mata tidak dapat diganti, hal ini diperkuat dengan beberapa alasan yang dituangkan dalam surat al-Baqarah ayat 178 dan surat Al-Maidah ayat 45 dimana mata harus diqhisas dengan mata, baik dala aspek metode pelukaan, maupun kualitas pelukaan dalam prakteknya harus dilakukan dengan seimbang antara korban dan pelaku, sehingga tidak boleh diganti dengan objek tubuh lainnya, sedangkan diyat diatas delik pelukaan mata adala 100 dinar.

\section{DAFTAR PUSTAKA}

\section{Buku}

[1] Al-Nawawi, Yahya. (1992). Minhaj al-Talibin, Lebanon: dar al-Fikr.

[2] Al-Jazairi, Abu Bakar Jabir. (1995). Minhaj Al-Muslim (cet. Ke-1). Beirut: Dar al Fikr,.

[3] Abdurrahman. Hukum Pidana Menurut Syari'at Islam. Jakarta: Rineka Cipta, 1992.

[4] Al Audah, Abd. Al. Qadir At Tasyari Al Jinayah Al Islamiy. Beirut: Dar Al Kitab Al

24 A. Djazuli, Fiqh Jinayah, Bandung; Raja Grafindo Persada, 1996, hal. 46.

25 Abdul Karim Zaidan, Al-Wajiz, 100 Kaidah Fiqh Dalam Kehidupan Sehari-Hari, Pustaka AlKautsar, Jakarta, 2008, hal. 132 
Arabim Beirut.

[5] As-Syatibi, Abu Ishaq Al-Muqafaqat Fi Ushul A;-Syariah, Juz II, Kairo: Mustafa Muhammad.

[6] Djazuli, A. (1996), Fiqh Jinayah, Bandung: Raja Grafindo Persada.

[7] Faquha, Ahkamul. (2007). Solusi Problematika Aktual Hukum Islam, Keputusan Muktamar, Munas, Dan Konbes Nahdlatul Ulama, (1926-2004 SM). Pen, Djamaluddin Miri Surabaya: Khalista.

[8] Hanafi,A. (1976). Asas-Asas Hukum Pidana Islam (cet. Ke-2). Jakarta: Bulan Bintang.

[9] Jamaa, La. (2013). Transplantasi Organ Tubuh, dalam Fiqh Kontemporer, Ambon, FSEI Press.

[10] Kusuma, Mahmud. (2009). Menyelami Semangat Hukum Progresif, Terapi Paradigmatic Bagi Lemahnya Penegakan Hukum Indonesia. Jogjakarta: Antony Lib-indonesia.

[11] Muchlis, Ahmad Wardi. (2004). Hukum Pidana Islam. Jakarta: Sinar Grafika.

[12] Scacht, Yoseph. (1964). An Introduction to Islamic Law. Oxford: Oxford Universty Press.

[13] Soekanto. Sosiologi Suatu Pengantar. Jakarta: Grafindo.

[14] Umar, Hasbi. (2007). Nalar Fiqih Kontemporer. Jakarta: Gaung Persada Press.

[15] Zaidan, Abdul Karim. (2008). Al-Wajiz, 100 Kaidah Fiqh Dalam Kehidupan Sehari-Hari. Jakarta: Pustaka Al-Kautsar.

\section{Jurnal dan Lain-Lain}

[16] Al-Bujayrami, Sulayman. (1998). Hashiyah Sharsh Manjhaj al Tjullab, Vol. 1, Lebanon, Dar, Al-Fikr.

[17] Sulaiman bin Abu Daud, Sunan Abu Daud, Vol. 2 (tt: Dar al-Fikr, tt).

[18] Madjid, Syachril Abdul. (2010), Implementasi Undang-Undang Pelayaran Nomor 17 Tahun 2008, Tentang Kelautan Kapal, Dalam Skripsi Fakultas Syariah IAIN Ambon,. 